SHS Web of Conferences 14,01017 (2015)

DOI: $10.1051 /$ shsconf/20151401017

(c) Owned by the authors, published by EDP Sciences, 2015

\title{
The Current Situation of Sports Culture Construction in Five Universities of Baoding
}

\author{
Yuanhui Zhang and Shen Cao \\ Shijiazhuang Institute of Technology, 050228 Shijiazhuang Hebei, China
}

\begin{abstract}
It has very important significance of university sports culture on the construction of colleges and universities to carry out quality education, which is the impact of the objective conditions on the construction of university sports culture. This article uses the literature method, questionnaire survey method to investigate the situation of sports culture construction of 5 universities in Baoding, analyzes the problems and causes, and provides feasible suggestions to further promote the construction of sports culture for universities in Baoding.
\end{abstract}

Keywords. construction of sports culture; investigation of present situation; feasible suggestions

\section{The purpose of research}

Sports culture construction is an important part of the construction of campus culture and spiritual civilization, and the university sports culture as a part of campus culture, is the comprehensive summation created the teacher-student interaction in the process of college sports spirit and material culture. Let the university sports culture play its due role, makes the contribution for the quality education of College students.

\section{The significance of research}

The sports culture construction of university campus can promote the vigorous development of sports culture, promote the students' enterprising spirit and the courage to open up the unity of the quality, promote the health of students, and improve their comprehensive quality. So the construction of sports culture in the campus culture plays a very important role, it has the very realistic significance situation investigation on the construction of university's sports culture.

\section{The object and method of research}

\subsection{The object of research}

Five colleges and universities in Baoding area as the research object in this paper.

\subsection{The method of research}

\subsubsection{Literature}

Through access to education, social science, physical health and physical education evaluation system and other aspects of the books, and access to relevant documents from the Internet, refer to the relevant literature for writing this article to collect detailed information.

\subsubsection{Questionnaire}

Firstly, design questionnaire for teachers and students in five colleges and universities in Baoding area. Secondly, 100 questionnaires were issued to every school. Thirdly, effectively recover and summarize all questionnaires.

\section{The research results and analysis}

A total of 500 questionnaires were issued, 500 were recovered, 480 effective questionnaires were pooled analysis, no difference, not refined distinguish. One of 160 copies of teachers questionnaires were completely effective recovery, and fuzzy analysis.

Results: $40.5 \%$ of the students like most sports skills, physical health class is $10.2 \%$, sports humanistic class is $10.8 \%$, sports information class is $30.7 \%$, sports art is $8.8 \%$.

In influencing factors of students' sports knowledge, ability level of physical education teachers is most important, accounting for $28.2 \%$, while $49.6 \%$ of students think that the ability level of physical education teachers for their knowledge of the sport to master "has a larger effect", think "great influence" has $22.7 \%$.

The situations of students participate in sports and cultural activities: 1$)$ regularly $(2 \sim 3$ times weekly) the number of ratio is $36.7 \% ; 2$ ) occasionally the number of 
Table 1. Sports culture environment evaluation on students of colleges and universities.

\begin{tabular}{llllllll}
\hline Options & $\begin{array}{l}\text { Types of physical } \\
\text { activity }\end{array}$ & Coverage & Venues conditions & Faculty & Architecture & Consultation & Others \\
\hline Satisfaction & $12 \%$ & $34 \%$ & $25 \%$ & $35 \%$ & $12 \%$ & $5 \%$ & $3.5 \%$ \\
Dissatisfied & $88 \%$ & $66 \%$ & $75 \%$ & $65 \%$ & $88 \%$ & $95 \%$ & $96.5 \%$ \\
\hline
\end{tabular}

ratio is $48.9 \%$; 3 ) rarely the number of ratio is $12.6 \%, 4$ ) almost not the number of ratio is $1.8 \%$.

Analysis: students participate in sports and cultural activities or less, occasionally attending or occupy the majority, so the enthusiasm for sports cultural activities lack.

Environmental evaluation of students' sports culture (see table 1)

Seen from the table 1, the current students' evaluation for college sports culture environment is still at a low level, sports type is too small, the venue conditions are not compliance and the teachers' strength is not enough. Many factors influence the sports culture and education diversity.

\section{The overall analysis and thinking}

Through the questionnaire analysis, the most favorite sport in five colleges students is still athletic class such as basketball, football etc. Analysis of reasons: 1) because of the influence of competitive sports; 2) college sports theory class with more prominent problems; 3) the importance of the schools and sports theory class is not enough and Inadequate understanding of sports theory class. At the same time, the survey also showed that: $28.2 \%$ of the students think that their physical education teachers are excellent, $22.7 \%$ of the students think that their teacher is poor. In this and the emergence of new problems: "the teacher's professional skill is really bad? or other reasons?" It is worth thinking about. So to stimulate innovation of physical education teachers' teaching enthusiasm is very important. The reason of University PE Teachers needs to continue to improve teaching methods, positive interaction, and guide students' physical exercise in class and after class.

The campus sports culture material level still need to vigorously develop the sports venues, facilities and equipment is an important manifestation of college sports material culture, the school should increase physical capital investment to meet the normal requirements of College students.

PE teachers should play an active role in college physical education. Change the traditional concept that the teacher just sports as imparting knowledge and skills, ignoring the education function of sports in the emotional aspects, pay attention to the development of the personality of students, improve the students' understanding of the level of synchronization. At the same time, colleges and universities should enlarge the resources of college physical education teachers' talent reserve. Strengthen the sports teachers in the cultural literacy, cultivation of moral quality and dedication etc. Add new weather for our campus sports culture.
The student's own sports cultural literacy needs to be improved. Some students do not pay attention to physical exercise, neither to cultivate the habit of exercise, no health science development outlook formation; addicted to smoking, alcohol abuse, Internet and other unhealthy lifestyle. These problems are the result of combined action of various factors on the results. These problems are very serious. This requires physical education teachers to provide real assistance to them, through the positive and effective guidance, to improve their enthusiasm and initiative, let them actively into the construction of the campus sports culture.

\section{Conclusions and suggestions}

(1)The campus sports material culture

Strengthening the construction of venues, equipment and facilities in Colleges and universities to meet the needs of students and school sports and cultural development

(2)The sport's teachers

Colleges and universities should increase the resources of college physical education teachers' talent reserve. Strengthen the sports teachers in the cultural literacy, cultivation of moral quality and dedication etc.

(3)The development of the students

Provide real assistance for them, effectively through active guidance, improve their enthusiasm and initiative, and let them actively into the construction of the campus sports culture

(4)Improving the professional quality of PE teachers in Colleges and universities

Change the traditional concept that the teacher just sports as imparting knowledge and skills, but ignore the education function of sports in the emotional aspects, pay attention to the development of the personality of students, and improve the students' understanding of the level of synchronization.

(5)Strengthen the sports exchanges between schools to enrich students' extracurricular Sports activities

Sports activity itself has a strong appeal and unlimited fun, such as discussion between teachers can adopt a way of physical education teaching staff, excellent lectures, learn from each other and students' sports friendly way, improve students' lack of understanding for sports culture, strengthen the construction of campus sports culture.

\section{References}

1. Zhu, X.Y. \& Du, J. Discussion on higher school function of campus sports culture and construction 
[J]. Journal of Northeast Agricultural University (Social Science Edition), 2011, 05.

2. Xu, C.H. \& Lu, Z. Construction of Yunnan province has the national minority sports cultural characteristics of the campus sports culture research [J]. Bulletin of Sport Science and Technology, 2010, 07.

3. Ma, H.L. Campus sports culture and extracurricular sports activities [J]. Journal of Shanxi University of Finance and Economics (Higher Education Edition), 2012, 02.
4. Zhong, Z.X. \& Li, L. College students' cognition of campus sports culture status and intervention strategy [J]. Journal of Jilin Institute of Physical Education, 2009, 03.

5. Bao, G.L. \& Liu, Y.Q. The influence on the construction of sports culture in campus of University of Heilongjiang Province, the ice snow sports [J]. China Winter Sports, 2009, 06.

6. He, W.T. Effect of campus sports culture to the construction of harmonious campus [J]. Journal of Chengdu Electromechanical College, 2012, 03. 